Kanık Uysal, P. (2021). Akıcı okuma, okuduğunu anlama ve kelime hazinesinin geliştirilmesinde kullanılan bir yöntem: okuma tiyatrosu. Ana Dili Eğitimi Dergisi, 9(1), 76-93.

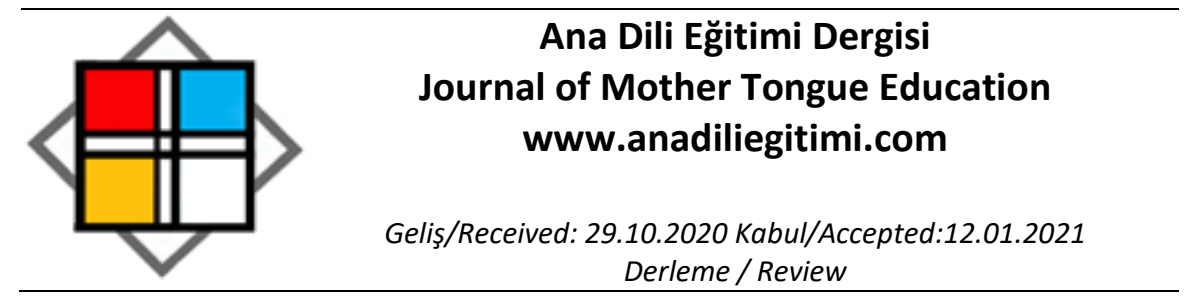

\title{
Akıcı Okuma, Okuduğunu Anlama ve Kelime Hazinesinin Geliştirilmesinde Kullanılan Bir Yöntem: Okuma Tiyatrosu
}

\author{
PInar KANIK UYSAL*
}

Öz

Okuma tiyatrosu akıcı okuma, kelime öğretimi ve okuduğunu anlama stratejilerini içinde barındıran ve öğrencilerin hem akıclık hem de anlama becerilerinin gelişimine katkı sağlayan bir öğretim yöntemidir. Ezber, kostüm, sahne, dekor ve uzun süren hazırlıklar gerektirmemesi yönüyle tiyatrodan ayrılmakta ve aslen okuma becerilerine odaklanmaktadır. Okuma düzeyi birbirinden farklı olan öğrencilerin bulunduğu sınıf ortamlarında, okuma güçlüğü yaşayan öğrenci gruplarında ve ikinci dil öğretiminde kullanılabilmektedir. İçerisinde birden çok stratejiyi barındıran bu yöntemde akıcı okuma için model okuma, koro okuma ve eşli okuma; okuduğunu anlama için sesli düşünme, soru sorma, özetleme, soru oluşturma ve metni yeniden anlatma; kelime öğretimi için anahtar ve anlamı bilinmeyen kelimelerle çalışma, kelimelerin anlam özellikleri ve birbiriyle olan anlam ilişkileri üzerinde durma stratejileri kullanılabilmektedir. Bu çalışmada okuma tiyatrosunun dayandığı kuramsal temelleri tanıtmak ve uygulama aşamalarını açıklamak amaçlanmakta, yöntemin niçin ve nasıl kullanılması gerektiği anlatılmaktadır. Bu yöntemin hem sosyal bilimler hem de fen bilimleri alanında kullanılabileceği, öğrenciler için öğrenirken eğlenme ve okuma becerilerini geliştirme fırsatı sunan bir sınıf ortamı sağlayacağı düşünülmektedir.

Anahtar Kelimeler: Okuma tiyatrosu, akıcı okuma, okuduğunu anlama stratejileri, kelime öğretimi.

\section{A Method Used to Develop Reading Fluency, Reading Comprehension and Vocabulary: Readers Theater}

\begin{abstract}
Readers theater supports reading fluency by students, comprehension of what is read, and development of vocabulary. It differs from the theater in terms of not requiring memorization, costumes, stage, sets, and long-term preparations and focuses on reading skills. It can be used in class environments containing students with different reading levels, for student groups experiencing reading difficulties, and in second-language teaching. This method, involving many strategies, uses strategies such as model reading, choral reading, and partner reading for reading fluency; thinking aloud, asking questions, summarizing, creating questions, and re-explaining the text for reading comprehension; and work on key and misunderstood words, meaning features of words and meaning relationships, and use of vocabulary for vocabulary teaching. This study aims to describe the conceptual basis and implementation stages for readers theater, a reading method providing an entertaining learning environment for teachers in classrooms. It is thought that this method, offering students the opportunity for entertainment with learning and development of reading skills, can be used by social sciences and natural sciences.
\end{abstract}

Keywords: Readers theater, reading fluency, reading comprehension strategies, word teaching.

\footnotetext{
* Dr. Öğr. Üyesi, Ordu Üniversitesi, Eğitim Fakültesi, Türkçe ve Sosyal Bilimler Bölümü, Ordu, pinaruysal32@gmail.com, ORCID: 0000-0003-1208-9535
} 


\section{Giriş}

Okuma, üst düzey düşünme becerilerine kaynaklık eden temel bir beceridir. Günlük yaşamın hemen hemen her alanında defalarca kullanıldığı ve birçok alanda diğer tüm öğrenme biçimlerinin temelini oluşturduğu için kritik öneme sahiptir (Bouchamma, Poulin ve Ruel, 2014). Yaşam boyu öğrenen bireylerden oluşan bir toplum yapısının oluşması için dil becerileri gelişmiş, okuma becerilerinde yetkinleşmiş, kendini iyi bir okuyucu olarak tanımlayabilen bireylerin yetiştirilmesi gerekmektedir. National Reading Panel [NRP] (2000) tarafından belirlenen ve başarılı bir okuma becerisi için gerekli olan temel okuma becerileri arasında ses farkındalı̆̆ı, akıcı okuma, kelime hazinesi ve anlama stratejileri bulunmaktadır. Bu değişkenlerden her biri birbirinin tamamlayıcısı niteliğindedir. Kelime çözümleme ve okuduğunu anlama ile hiyerarşik bir ilişki içerisinde olan sesbilgisel farkındalık becerisinin (Güldenoğlu, Kargın ve Ergül, 2016) akıcı okuma ve okuduğunu anlama becerilerinin kazanılmasında önemli rolü bulunmakta, sesbilgisel farkındalık becerisi gelişmiş okuyucular kelimeleri daha çabuk ve doğru çözümleyebilmektedir (Turan ve Akoğlu, 2011). Yapılan çalışmalar sesbilgisel bilgi ve becerilerinin (Durgunoğlu ve Öney, 1999; Güldenoğlu, Kargın ve Miller, 2015; Öney ve Durgunoğlu, 1997) ve akıcı okuma becerilerinin (Baştuğ ve Akyol, 2012; Yıldırım ve Rasinski, 2014; Yıldız ve diğerleri, 2014) okuduğunu anlama başarısı için önemli bir yordayıcı olduğunu ortaya koymaktadır. Stanovich (1980) zayıf okuyucular ile iyi okuyucular arasındaki en büyük farklardan birinin kelime tanıma sırasında ortaya çıktığını, Miller ve Schwanenflugel (2008) akıcı bir şekilde okuyanların okuduğunu daha iyi anlayan okuyucular olduğunu, Baydık (2011) okuma güçlüğü yaşayan öğrencilerin çoğunluğunun akıcı okuma sorunları yaşadı̆̆ını belirtmektedir.

Okuma eğitiminde önemli bir role sahip olan akıcı okumanın (Young ve Rasinski, 2009) teorik temelleri otomatiklik teorisine dayanmakta ve bu teori, okuyucular kelime tanımada otomatik veya akıcı hale geldikçe, bilişsel kaynaklarının okuduğunu anlama için serbest bırakıldığını savunmaktadır. Otomatiklik; doğru, zahmetsiz ve hızlı kelime tanıma olarak tanımlanmakta (LaBerge ve Samuels, 1974) ve kelime tanıma görevi otomatikleştirildiğinde, okuyucuların dikkatlerini başka bir göreve, bu durumda okuduğunu anlamaya aktarabildiği kabul edilmektedir. Kelime tanımaya odaklanma intiyacının azalması, dikkatin metni anlamaya odaklanmasını sağlamaktadır. Dikkatin anlamaya odaklanmasını sağlamak için otomatikleşme, bunun sağlanabilmesi için de okumaya yeterince zaman ayrılarak tekrarlı okuma çalışmaları yapılması gerekmektedir. Samuels (1979) tekrarlı okumanın kelime tanıma ve okuma hızı üzerinde etkili olduğunu ve kazanılan bu otomatikliğin daha önceden okunmamış yeni metinlerle karşılaşıldığı zaman da etkisini sürdürdüğünü tespit etmiştir. Bu bulgu, Lee ve Yoon (2017) ve Therrien (2004) tarafından yürütülen meta analiz çalışmalarıyla da desteklenmiştir. Bu nedenle akıcı okuma çalışmalarında tekrarlı okumanın vazgeçilmez bir yeri bulunmaktadır. Ancak tekrarlı okuma çalışmaları kelime tanıma ve okuma hızı üzerinde etkili olmakla birlikte akıcı okumanın bir diğer boyutu olan prozodinin gelişimi için yetersiz kalmakta, bu becerinin gelişimi için okuyucuya model sunulması gerekmektedir (Zutell ve Rasinski, 1991). Okuduğunu anlamanın önemli bir habercisi (Schreiber, 1991) ve akıcı okumanın önemli bir unsuru olan prozodi; "metni, ifade edici bir ritim ve uygun ses tonu deseni içerisinde, anlam ünitelerine dikkat ederek okuma" (Dowhower, 1991, s. 166) olarak tanımlanmaktadır. Araştırmalar sesli okumadaki prozodi ölçümleri ile sessiz okuduğunu anlama arasında önemli bir ilişki olduğunu ortaya koymakta (Daane, Campbell, Grigg, Goodman ve Oranje, 2005), akıcı okuma sadece sesli okumayla ilişkili bir beceri gibi algılanmasına rağmen sesli okumadaki akıclık sessiz okumadaki okuduğunu anlama becerisini de etkilemektedir (Reutzel, Jones, Fawson ve Smith, 2008). Bu nedenle okuma eğitiminde prozodi becerisinin gelişimine katlı sağlayacak yöntem ve tekniklerin kullanılması, tekrarlı okuma çalışmalarının bunlarla desteklenmesi gerekmektedir. Bu noktada da devreye model okuma ve eşli okuma çalışmaları girmektedir. Model okumada; sesli kitap, öğretmen ya da akranlar aracılığıyla öğrenciye uygun prozodik okuma örneği sunulmakta ve öğrenciden dinleme yoluyla bu beceriye dair farkındalık kazanması beklenmektedir. Eşli okumada öğrenciler metni birlikte okumakta, öğrencilerden biri metnin bir bölümünü yüksek sesle okurken diğeri onu takip ederek gerekirse hatasını düzeltmesi için arkadaşına yardım etmektedir (Stahl ve Heubach, 2005). Bu yöntemler sayesinde öğrenci; öğretmeninden ve arkadaşlarından dinlediği örnek okumaları kendine model almakta, prozodik okumanın nasıl olduğunu uygulamalı bir şekilde görmekte ve arkadaşlarından dönüt alarak okumasını düzeltme fırsatı yakalamaktadır. Alanyazında yürütülen 
çalışmalar (Stahl ve Heubach, 2005; Therrien, 2004; Vaughn ve diğerleri, 2000) model okuma, tekrarlı okuma ve eşli okuma yöntemlerinin akıcılığı artırmak için güçlü araçlar olduğunu ortaya koymaktadır.

Başarılı bir okuma becerisinin bir başka değişkeni anlama stratejileridir. Okuduğunu anlama stratejilerinin kullanımı ile akıcı okuma arasında önemli bir ilişki bulunduğu ve akıcı okumanın anlama stratejilerinin kullanımını desteklediği bilinmektedir (Beydoğan, 2012). Ateş ve Yıldıım (2014) iyi bir kelime tanıma ve akıcı okuma becerisinin okuduğunu anlama için çok önemli iki ön koşul olduğunu ancak metinlerden anlam elde edebilmek için bilişsel süreçlerin devreye girdiğini, bunun da çeşitli anlama stratejilerini içerdiğini belirtmektedir. Okuduğunu anlama, sadece okumanın öğrenilmesiyle birlikte kendiliğinden gelişen bir beceri olmadığından (Moats, 1999) strateji öğretimi okuduğunu anlama öğretiminin temel bileşenlerinden biri olarak karşımıza çıkmakta ve öğrencilere okuduklarından anlam oluşturmak için ihtiyaç duydukları okuma stratejilerinin öğretilmesi gerekmektedir (Prado ve Plourde, 2011). İyi okuyucuların sadece akıcı okumada değil okurken kullandıkları stratejilerde de de zayıf okuyuculardan daha iyi oldukları bilinmekte, Kuruyer ve Özsoy (2016) tarafından iyi okuyucuların üstbilişsel okuma becerileri gösterdiği ve iyi bir stratejist oldukları belirtilmektedir. İyi okuyucular; hangi stratejiyi, ne zaman, nasıl kullanacağı, metnin türüne ve yapısına göre nasıl şekillendireceği konusunda bilgi sahibi olan ve kendi okuma sürecini değerlendirebilen okuyuculardır (Pressley ve Gaskins, 2006). Okuduğunu anlama stratejileri öğretiminin okuduğunu anlama becerilerinin geliştirilmesinde etkili olduğu sonucuna ulaşan birçok araştırma (Ateş ve Yıldırım, 2014; Baydık, 2011; Buxton, 2017; Dole, Duffy, Roehler ve Pearson, 1991; McNamara, 2007; Pressley, Johnson, Symons, Mcgoldrick ve Kurita, 1989) okuduğunu anlama başarısının artırıması için strateji öğretiminin yapılması gerektiğini savunmaktadır. Pressley ve Gaskins (2006) okuduğunu anlama stratejileri öğretiminin okulun ilk günü itibariyle başladığını ve öğrencilerin öğretmenlerini izleyerek bu stratejileri öğrendiklerini ve her sınıf düzeyinde strateji öğretimi yapılması gerektiğini ifade etmektedir. Öğretmenlerin okuduğunu anlama stratejileri kullanımında öğrencilerine model olmaları ve doğrudan öğretim yoluyla onlara strateji öğretmeleri, öğrencilerin bu becerileri kazanmaları ve stratejik birer okuyucu olmaları açısından büyük önem taşımaktadır (Dole ve diğerleri, 1991; Duffy, Roehler ve Herrmann, 1988; National Reading Panel, 2000; Pressley, Wharton-Mcdonald, Mistretta-Hampston ve Echevarria, 1998).

Okuduğunu anlama stratejilerinin öğretilmesi aynı zamanda okuma becerisinin bir diğer önemli değişkeni olan kelime bilgisinin artırılmasında da önemli rol oynamaktadır (Boulware-Gooden, Carreker, Thornhill ve Joshi, 2007). Kelime bilgisi, anlamın inşa edilmesinde kritik bir öneme sahip olduğu için okuduğunu anlamanın yüksek bir yordayıcısı olarak kabul edilmektedir (Biemiller ve Slonim, 2001). Okuyucuların dinlediklerini, okuduklarını eksiksiz ve doğru anlayabilmeleri için sözcükleri doğru anlamlandırmaları gerekmekte ve kelime dağarcıklarının zengin olmasına ihtiyaç duyulmaktadır (Karatay, 2007). Biemiller ve Slonim (2001) üçüncü sınıfta kelime bilgisinde geride kalan öğrencilerin, okul süreleri boyunca geride kalacaklarını bildirmektedir. Bu nedenle okulun ilk yılından itibaren amaçlı, sistemli ve planlı bir şekilde kelime öğretimi çalışmalarının yapılması, öğrencilerin kelime dağarcıklarının zenginleştirilmesi gerekmektedir (Göçer, 2009; Karadağ ve Kurudayıŏlu, 2010). Okuduğunu anlamayı geliştirmek için akıcı okuma, kelime bilgisi ve strateji kullanımının birlikte ele alınması ve bu becerilerin birbirini desteklemesi sağlanmalıdır (Baydık, 2011; Pressley, 2002). Tüm bunlardan hareketle de başarılı bir okuma becerisi için bu temel değişkenlerin öğretimini içeren bir okuma eğitimi yaklaşımına ihtiyaç duyulmaktadır. Alanyazın incelendiğinde okuma eğitiminde kullanılabilecek ve içeriğinde akıcı okuma, anlama stratejileri ve kelime öğretimi çalışmalarını içeren bir yöntem olarak okuma tiyatrosunun ön plana çıktığı görülmektedir.

\section{Okuma Tiyatrosu}

Okuma tiyatrosu; öğrencilerin akıcı okuma, okuduğunu anlama ve kelime hazinesi gelişimini destekleyen, öğretim programına paralel olarak ders içeriğine sindirilebilen bir öğretim yöntemidir. Alanyazında yürütülen çalışmalar okuma tiyatrosunu; okuma akıcılığını artırmak için etkili bir öğretim stratejisi (Young, Mohr ve Landreth, 2020), okuma pratiği yapmak için önemli bir öğretim yöntemi (Hudson, Lane ve Pullen, 2005), başarılı bir akıcılık eğitiminin birçok özelliğini içinde barındıran etkili bir öğretim yaklaşımı (Rasinski ve Young, 2017) ve öğrencileri bir seyirci için senaryo metinlerini prova 
etme ve sunmaya teşvik eden eğitici bir faaliyet (Worthy ve Prater, 2002) olarak tanımlamaktadır. Okuma tiyatrosunu tanımlamak için kullanılan kavramlar konusunda alanyazında bir birlik sağlanamadığı; araştırmalarda yaklaşım, strateji ve yöntem kavramlarının birbirinin yerine kullanıldığı görülmektedir. Bu çalışmada ise Fer'in (2020, s. 256) yöntem terimi için kullandığı "öğretim için seçtiğimiz ve izlediğimiz yol, seçtiğimiz stratejiyi uygulama yolu" tanımı temel alınarak "öğretim yöntemi" kavramı kullanıımıştır.

Okuma tiyatrosu öğrencilere tekrarlı okumalar yapmaları için keyifli ve gerçek bir neden sunarak onların okumaya ayırdığı zamanı artırmayı hedeflemektedir. Başarılı bir okuyucu olmak için okuma çalışmalarına yeterince zaman ayrılması, bunun gerçekleşebilmesi için de öğrencilere onları motive edecek bir gerekçe sunulması gerekmektedir. Okurken eğlenmek, öğretmen ve akran desteğini yanında hissetmek öğrencileri okuma çalışmalarına motive etmekte ve onlar için sürecin daha kolay geçmesini sağlamaktadır. Okuma tiyatrosu sahne, kostüm ve ezber gerektirmemesi yönüyle tiyatrodan ayrılmakta ve sınıf ortamında kolaylıkla uygulanabilmektedir. Öğretmenler, öğrencileriyle sunum çalışmaları yapmalarına engel teşkil edecek maddi sorunlar ve mekân sıkıntısıyla karşılaşmamakta, bir başka deyişle onları kısıtlayan ve onların dışında gelişen dış faktörlerle baş etmek zorunda kalmamaktadır. Bu yöntem bir metin aracılığıyla sınıf ortamında kolaylıkla uygulanabilmekte, aylarca süren bir hazırlık sürecine gerek duyulmamaktadır. Önemli olan öğrencilerin düzeyine ve ilgi alanlarına uygun, karşılıklı konuşmaları içeren bir metnin seçilmesi ve senaryo metnine dönüştürülmesidir. Doğru metin seçilip senaryo metnine dönüştürüldükten sonra sıra metni anlama ve akıcı okuma çalışmalarına gelmektedir. Metin eşliğinde yürütülen akıcı okuma ve okuduğunu anlama çalışmaları sonunda öğrenciler hazırladıkları sunumu arkadaşlarına, öğretmenlerine, okul idaresine, velilere ya da misafirlere sunmaktadır. Sunum öncesinde yürütülen model okuma, tekrarlı okuma, eşli okuma, okuduğunu anlama ve kelime öğretimi çalışmaları ile öğrencilerin okuma başarılarını artırmak; sunum sonrasında yapılan değerlendirme çalışmaları ile de öğrencilerin kendi ve arkadaşlarının okumalarıyla ilgili farkındalık kazanarak öz ve akran değerlendirme becerilerini geliştirmelerini sağlamak hedeflenmektedir.

Öğrencilerin okuma becerilerinin gelişimine yardımcı olmak için tasarlanmış, uygulamaya dayalı bir yöntem olan okuma tiyatrosu okul müfredatına paralel olarak ders içeriğine sindirilebilmekte ve farklı derslerde kullanılabilmektedir. Bu yöntem sosyal bilimler (Dixon, 2010; Uribe, 2019) ve fen bilimleri (Kinniburgh ve Shaw, 2007) alanlarında da kullanılmaktadır. Uribe (2019) öğretim programı temelli okuma tiyatrosu uygulamalarının okuma akıcılığı ve anlamayı artırmanın yanı sıra edebiyat, matematik, fen bilimleri veya sosyal bilimler dahil olmak üzere herhangi bir içerik alanındaki bilginin akılda kalmasını sağlamak için kullanılabileceğini ifade etmektedir.

\section{Okuma Tiyatrosunu Destekleyen Kuram ve Modeller}

Okuma tiyatrosunun okuma eğitimindeki yerinin kavranabilmesi için bu yöntemin ilişkili olduğu kuram ve modellerin bilinmesi gerekmektedir. Okuma tiyatrosunun ilişkili olduğu kuram ve modeller belirlenirken Carrick (2006)'den yararlanılmış ve bu kuramlarla ilgili kısa açıklamalar Tablo 1'de gösterilmiştir.

Tablo 1.

Okuma Tiyatrosunun ilişkili Olduğu Kuramlar

\begin{tabular}{ll}
\hline Kuram/Model & Açıklaması \\
\hline $\begin{array}{l}\text { Otomatiklik Teorisi (Otomatik Bilgi İşleme } \\
\text { Modeli) }\end{array}$ & $\begin{array}{l}\text { Bir bilgi ya da becerinin, yoğun bir zihinsel çaba } \\
\text { gerektirmeksizin hızlı ve hatasız biçimde } \\
\text { (LaBerge ve Samuels, 1974) }\end{array}$ \\
uygulanacak şekilde öğrenilmesidir.
\end{tabular}

Sosyal Yapılandırmacılık Kuramı (Vygotsky, 1978)
Çocuklar akranları, öğretmenleri, aileleri ya da çevreleri ile olan toplumsal etkileşimleri sonucu öğrenirler. 
Tekrarlı Okuma Modeli

(Samuels, 1979)

Okur Tepki Teorisi

(Rosenblatt, 1978)

İ̧̧ Birliğine Dayalı Öğrenme

(Johnson ve Johnson, 1985; Slavin, 1987)
Metinlerin akıcı okumaya ulaşılıncaya kadar tekrar edilerek okunması ve kelimelerin hızlı ve doğru tanınması sayesinde dikkatin anlama yoğunlaşmasıdır.

Okuma, okuyucu ve metin arasında anlamın yapılandırılması sürecidir. Okuma sürecinde hem metin hem de okuyucu birbirini etkilemektedir.

Bir görevi tamamlamak için ortak bir hedefte buluşan öğrencilerin birbirlerinin öğrenmelerine yardımcı olması ve grup içindeki her öğrenciye eşit fırsat tanınmasıdır. Öğrencilerin bilişsel ve sosyal öğrenme becerileri birlikte gelişir.

Tablo 1'de açıklaması verilen kuram ve modeller okuma tiyatrosunun kuramsal temellerini oluşturmaktadır. Vygotsky (1978)'nin sosyal yapılandırmacılık kuramı, öğrencilerin bilgiyi sosyal bağlamda başkaları ile etkileşimi sonucunda kurguladığını belirtir. İş birliğine dayalı öğrenmede öğrenciler ortak hedeflerini gerçekleştirebilmek için birlikte çalışırlar (Johnson ve Johnson, 1985). Okuma tiyatrosu, öğrencilere metin üzerinde çalışırken ve senaryoyu uygularken akranları ile etkili etkileşim kurmaları için büyük bir fırsat sağlar. Bir görevi tamamlamak için birlikte çalışan öğrenci grubunun hem bilişsel hem de sosyal öğrenme becerisi gelişir. Aile-çocuk, öğretmen-öğrenci ve öğrenci-öğrenci arasındaki ilişkiler ve öğrenme sürecine birlikte katılım, okumayı öğrenme ve geliştirmede önemli unsurlardır (Yıldırım, 2010). Tekrarlı okuma modeli, öğrencilerin tekrarlı okumalar sayesinde akıcı okuma becerilerinin geliştiğini belirtir. Düzenli olarak yapılan tekrarlar sayesinde, okuma problemi yaşayan öğrencilerin okuma hatalarında azalma, okuduğunu anlama becerilerinde ve okuma motivasyonlarında gelişme görülür (Yılmaz, 2006). Okur Tepki Teorisi (Rosenblatt, 1978) öğrenci ve metin arasında karşılıklı bir etkileşim olduğunu belirtir. Okuma tiyatrosunda okuma-anlama çalışmaları esnasında her öğrenci metni bir de öğretmeninin ve arkadaşlarının bakış açısıyla görme, yorumlama şansı yakalar. Bu nedenle bahsi geçen tüm bu kuram ve modellerin okuma tiyatrosunu bir yönüyle tamamladığı ve desteklediği görülmektedir.

\section{Okuma Tiyatrosu Niçin Kullanılır?}

Okuma tiyatrosu sahne, kostüm, ezber, aylar süren hazırlık ve özel bir alan gerektirmediği için kısa sürede ve kolay gerçekleştirilebilen bir yöntemdir. Ders yılı içerisinde istenilen zaman diliminde ve defalarca yapılabilme esnekliğine sahiptir. Bir oyun çıkarma kaygısıyla aylar süren hazırlık gerektirmemesi, ezber olmaması, özel kıyafetlere ihtiyaç duyulmaması stressiz ve keyif almaya yönelik çalışmaların yapııması için kolaylık sağlar. Öğrencilere tekrar tekrar okuma yapma fırsatı sağlayarak okuma pratikleri için bir neden sunar. Öğrenciler sürecin her aşamasında aktiftir. Senaryo metninin dönüştürülmesi ya da yazılması aşamasından okuma-anlama, eşli okuma ve grup çalışmalarından sunuma kadar her öğrenci sürece dâhil olmakta, çalışmanın bir boyutuyla meşgul olmaktadır. Okuma tiyatrosunun niçin kullanılması gerektiği şu şekilde özetlenebilir:

Kısa sürede tamamlanır ve sınıf ortamında rahatlıkla hem akıcı okuma ve okuduğunu anlama hem de sunum çalışmaları yürütülebilir.

Her sınıf düzeyinde kullanılabilme esnekliğine sahiptir. İlkokulda, ortaokulda, lisede hatta lisans düzeyinde kullanılabilir. Sosyal bilimler ya da fen bilimleri alanlarından seçilen ve ilgi duyulan bir konu seçilerek kullanılabilir.

Maddi yetersizlikler ve mekân sıkıntısı nedeniyle öğretmenlerin hareket alanını daraltmaz tam tersine öğretmene kendi sınıf ortamında ve bir senaryo metni eşliğinde sunum yapma olanağı sunar.

İş birliği içinde çalışmayı, akran desteğini ve model alarak öğrenmeyi içerir.

Öğrencilerin çok sayıda edebî metin ve edebî türle karşılaşmasını sağlar. Öğrenciler günlük hayatta karşılaşamayacağı sözcüklerle karşılaşır ve edebî dile ilişkin farkındalığı artar. 
Tekrarlı okumalar ve hazırlık süreci okuma başarısını artırdığı için öğrencilerin kendine olan güveninin artmasına yardımcı olur.

\section{Okuma Tiyatrosu Nasıl Uygulanır?}

Okuma tiyatrosunda ders işleme süreci uygulamaların yürütüleceği sınıf düzeyi ve öğrenci grubuna göre planlanmaktadır. Illkokulda haftanın 5 günü her gün bir oturum uygulanacak şekilde ortaokulda ise Türkçe dersi ya da diğer derslerin dağılımına göre planlama yapılması gerekmektedir. Bu çalışmada ilkokul düzeyinde uygulanabilecek beş günlük bir oturum planı örneği sunulmuştur. Bu örnek planda kullanılan akıcı okuma, okuduğunu anlama ve kelime öğretimi stratejileri sınıf düzeyi ve öğrenci grubuna göre değiştirilebilir, düzenlenebilir ve yeni stratejilerle zenginleştirilebilir. Bu uygulama örneği hazırlanırken öncelikle alanyazın taraması yapıımış ve araştırmalarda (Clark, Morrison ve Wilcox, 2009; Flynn, 2004; Keehn, 2003; Uribe, 2019; Young, Durham, Miller, Rasinski ve Lane, 2019; Young, Stokes ve Rasinski, 2017; Young ve Rasinski, 2009) kullanılan okuma tiyatrosu uygulama içerikleri ve okuduğunu anlama (Dole vd., 1991; NRP, 2000; Pressley vd., 1989) akıcı okuma (Rasinski, 2010) ve kelime öğretimi (Graves, 2016; Millî Eğitim Bakanlığı (MEB), 2005) stratejileri incelenmiş ve bu doğrultuda kullanılacak stratejilere karar verilmiştir. Okuma tiyatrosunun sınıfta uygulanması için takip edilebilecek adımlar aşağıda gösterilmiştir.

Okuma Tiyatrosu Ders işleme Süreci

\begin{tabular}{|c|c|c|c|c|}
\hline Gün & $\begin{array}{l}\text { Akıcl } \\
\text { Okuma }\end{array}$ & $\begin{array}{l}\text { Okuduğunu } \\
\text { Anlama }\end{array}$ & Kelime Bilgisi & Açıklama \\
\hline 1. Gün & $\begin{array}{l}\text { Model } \\
\text { okuma }\end{array}$ & $\begin{array}{l}\text { Sesli düşünme } \\
\text { Soru Sorma }\end{array}$ & $\begin{array}{l}\text { Anahtar } \\
\text { kelimelerle } \\
\text { çalışma }\end{array}$ & $\begin{array}{l}\text { Model okumada öğretmen kendisi okuyarak } \\
\text { öğrencilerine prozodik modelleme sunar. } \\
\text { Sesli düşünme, öğretmenin metni seslendirme } \\
\text { ve anlama çalışmaları esnasında süreçle ilgili } \\
\text { sesli düşünmesi, kullandığı stratejileri } \\
\text { öğrencilerine doğrudan öğretim yoluyla } \\
\text { aktarmasıdır. } \\
\text { Soru sorma; öğretmen tarafından okuma } \\
\text { öncesi, sırası ve sonrasında metin içi/metin } \\
\text { dışı sorular oluşturulmasıdır. } \\
\text { Anahtar kelimeler, okunacak metnin } \\
\text { anlaşılıması için kritik öneme sahip olan } \\
\text { kelimelerdir. Okuma öncesinde öğretmen } \\
\text { tarafından belirlenir ve bu kelimeler üzerinde } \\
\text { çalışılarak öğrencilerin ön bilgileri güçlendirilir. }\end{array}$ \\
\hline 2. Gün & $\begin{array}{l}\text { Koro } \\
\text { Okuma }\end{array}$ & Özetleme & $\begin{array}{l}\text { Anlamı } \\
\text { bilinmeyen } \\
\text { kelimelerle } \\
\text { çalışma }\end{array}$ & $\begin{array}{l}\text { Koro okumada öğrenciler hep birlikte aynı } \\
\text { anda okur. } \\
\text { Özetleme metin içi bilgileri hatırlama ve } \\
\text { anlama, önemli ile önemsiz bilgiyi ayırt etme, } \\
\text { metnin ana fikrini belirleme ve metni kendi } \\
\text { cümleleri ile yeniden ifade etmedir. } \\
\text { Anlamı bilinmeyen kelimeler, okuma sırasında } \\
\text { belirlenir. Öncelikle bağlamdan hareketle } \\
\text { anlam çıkarma çalışmaları yapııı. }\end{array}$ \\
\hline 3. Gün & $\begin{array}{l}\text { Eşli } \\
\text { okuma }\end{array}$ & $\begin{array}{l}\text { Soru } \\
\text { oluşturma }\end{array}$ & $\begin{array}{l}\text { Kelime } \\
\text { hazinesini } \\
\text { geliştirme }\end{array}$ & $\begin{array}{l}\text { Eşli okumada iki öğrenci hem dinleyici hem de } \\
\text { okuyucu görevlerini üstlenir ve birbirlerinin } \\
\text { okumasını değerlendirerek geri dönüt verir. } \\
\text { Soru oluşturmada öğrenciler metinle ilgili } \\
\text { kendileri soru çıkarır ve bu soruların cevap } \\
\text { anahtarını oluşturur. }\end{array}$ \\
\hline
\end{tabular}




\begin{tabular}{|c|c|c|c|c|}
\hline & & & & $\begin{array}{l}\text { Kelime hazinesini geliştirme çalışmalarında } \\
\text { kelimelerin anlam özellikleri ve birbiriyle olan } \\
\text { anlam ilişkileri üzerinde durulur. Eş anlam, zıt } \\
\text { anlam, eş sesli, mecaz anlam, deyim vb. } \\
\text { anlamlar çıkartılarak kelime ağı oluşturulur. }\end{array}$ \\
\hline 4. Gün & $\begin{array}{l}\text { Sunum } \\
\text { öncesi } \\
\text { prova }\end{array}$ & $\begin{array}{l}\text { Metni yeniden } \\
\text { anlatma }\end{array}$ & $\begin{array}{l}\text { Kelime } \\
\text { hazinesini } \\
\text { kullanma }\end{array}$ & $\begin{array}{l}\text { Sunum öncesi provada öğrenciler sunum } \\
\text { esnasındaki duruş yerlerini belirler ve diğer } \\
\text { gruplar önünde bir kez sunumların } \\
\text { gerçekleştirirler. } \\
\text { Metni yeniden anlatmada öğrenciler yen } \\
\text { öğrendikleri kelimeleri içerecek şekilde } \\
\text { arkadaşlarına metni sözlü anlatım yoluyla } \\
\text { özetlerler. } \\
\text { Kelime hazinesini kullanmada öğrenciler } \\
\text { öğrendikleri kelimeleri sözlü (metni yeniden } \\
\text { anlatmada) ya da yazılı anlatımlarında } \\
\text { kullanırlar. }\end{array}$ \\
\hline 5. Gün & Sunum & & Değerlendirme & $\begin{array}{l}\text { Öğrenciler sesli okuma performansların } \\
\text { dinleyiciler önünde sunarlar ve sunum } \\
\text { tamamlandıktan sonra gruplar birbirin } \\
\text { değerlendirirler. }\end{array}$ \\
\hline
\end{tabular}

Tüm bu aşamalar: "senaryo seç (hazır bir metin ya da uyarlanmış bir metin), senaryoyu tanı ve anla, görevleri dağıt (anlatıcı, karakter vb.), tekrar tekrar oku, bol bol pratik yap, hazır olunca sunum yap ve değerlendir." şeklinde özetlenebilir. Günlük uygulama süreci şu şeklide örneklendirilebilir:

PAZARTESi: Kullanılacak metinler tanıtılmadan önce metnin konusuyla ilgili öğrencilerin ön bilgileri harekete geçirilir. Bunun için görsellerden, videolardan ve edebî metinlerden yararlanılarak metinlerarası ilişki kurulur. Okuma öncesi açık uçlu sorularla öğrencilerin fikirleri alınır ve metne yönelik tahminlerde bulunmaları istenir. Wade ve Trathen (1989), okuma öncesinde sorulan soruların zayıf okuyucuların önemli bilgileri hatırlamasını kolaylaştırdığını tespit etmiştir. Okuduğunu anlama ve kelime hazinesi arasındaki güçlü ilişki (Pressley, 2002) göz önünde bulundurularak derste mutlaka kelime çalışmalarına yer verilir. İlk gün öğretmen tarafından belirlenen anahtar kelimeler üzerinde çalışıır. Belirlenen anahtar kelimelerin sayısının çok olmamasına özen gösterilerek metnin anlaşılmasında anahtar rol üstlenen kelimeler seçilir. Silverman ve Hartranft (2015) kelime sayısının çok olması okuma esnasında hatırlamayı zorlaştıracağı için okuma öncesinde 2-3 anahtar kelime üzerinde durulması gerektiğini savunur. Bu kelimelerden kelime ağları oluşturulur ve sınıf panosuna ya da kelime duvarına asılır. Sonrasında metin tanıtılır ve her öğrencinin elinde olacak şekilde metinler sınıfa dağıtııır. Öğretmen tarafından model okuma yapılır ve öğrencilerin bu okumayı takip etmesi sağlanır. Okuma bittikten sonra öğrencilerden öğretmenin okumasıyla ilgili yorum yapması istenir. Öğretmen hem prozodik modelleme hem de okuduğunu anlamanın takip edilmesi noktasında öğrencilerine model olur. Belirli noktalarda durarak öğrencilere sorular yöneltir. Sesli okumanın amacı, anlamaya yardımcı olabilecek akıcı ve prozodik okumayı modellemektir (Rasinski, 2010). Aynı zamanda öğretmen öğrencilerine iyi bir okuyucunun düşünme sürecini görebilmeleri adına "sesli düşünme"yi gösterir. Davey (1983) bu stratejinin öğrencilerin metin hakkında düşünmelerini sağladığını ve öğretmenin kullandığı anlama stratejilerini bu şekilde takip edebildiğini ifade etmektedir. Öğretmenin metindeki karakterler, olay örgüsü ve anahtar kelimeler hakkında hem kendisine hem de öğrencilerine sorular yöneltmesi okuma esnasında nasıl sorular sorulabileceğine dair öğrencilerine model olur. Okurken soru sormak, okumayı güçlendirmek için etkili bir stratejidir (NRP, 2000). Okuma esnasında metinde geçen kahramanların karakter özellikleri üzerinde durulur ve öğrencilere bu yönde sorular yöneltilerek karakterlerin özellikleri hakkında farkındalık oluşturulur. 
SALI: İkinci gün öğrenciler gruplara ayrılır, grup başkanı seçilir ve oluşturulan küçük gruplarda öğretmen bazı sorumlulukları öğrencilere bırakır. Ardından her grup metnini koro okuma yöntemiyle sesli okur. Koro okuma yönteminin birçok çeşidi olmasına rağmen kısaca bir grup olarak birlikte yüksek sesle okuma yapmak olarak tanımlanabilir (Rasinski, 2010). Bu yöntem öğrencilerin metnin tamamını birlikte okuması açısından önemlidir. Okuma çalışmalarının ne zaman tamamlanacağına metnin uzunluğu ve grup sayısının durumuna göre öğretmen karar verir. Okuma tamamlandıktan sonra öğrencilerin anlamını bilmediği kelimeler üzerine odaklanılır ve bu kelimelerin bağlamdan hareketle anlamlarının çıkarılması üzerinde durulur. Metnin bağlamından yararlanarak kelimelerin anlamını bulma çalışmaları öğrencilerin kelime hazinesini geliştiren önemli bir stratejidir (Buikema ve Graves, 1993). Kelimelerin anlamı önce grup içinde tartışıır, grup üyelerinden hiçbiri anlamı bulamadığı takdirde sözlüğe bakııı ya da öğretmenden yardım istenilir. Bu çalışma tamamlandıktan sonra öğretmen rehberliğinde metnin özeti çıkarılır. Illk haftalarda/aylarda öğretmen bu görevi kendisi üstlenir ve öğrencilerine model olur. Özet çıkarırken metindeki önemli ve önemsiz bilginin nasıl ayırt edileceği, ana fikre bağı kalmanın önemi, bir özette bulunması ve bulunmaması gereken unsurların neler olduğu öğrencilere gösterilir. ilerleyen süreçte bu görevi öğrenciler kendileri üstlenir. Metindeki önemli unsurlar ile önemsiz unsurları ayırt etme, ana fikri bulma ve özetleme çalışmaları okuduğunu anlama için önemli stratejilerdir (Dole ve diğerleri, 1991).

ÇARŞAMBA: Üçüncü gün rol dağılımı yapılır ve öğrenciler ikili gruplara ayrılır. Rol dağııımı yapılırken öncelikle gönüllülük esas alınır. Bir rolü birden çok öğrencinin istemesi durumunda öğrenciler arasında çekiliş yapılabilir. Bu sorunu çözmek adına, Young vd. (2017) taş, kâğıt, makas oyununu kullanmaktadırlar. Öğrenciler, bölümlerini seçtikten sonra eşli okuma çalışmalarına başlarlar. Öğretmen eşli okumalar esnasında öğrencilerinden metin ve karakterler üzerinde düşünmelerini ve metne yönelik sorular hazırlamalarını ister. Metinde geçen kahramanların karakter analizi yapılırken karakter analiz formları kullanılır. Her öğrenci hem okuyucu hem de dinleyici rolünü üstlendiği için dinleyici rolündeyken arkadaşının okuması tamamlandıktan sonra metinden sorular üreterek arkadaşına yöneltir. Öğrencilerin kendilerinin soru oluşturması, onların metni anlama oranını artırdığı (Joseph, Alber-Morgan, Cullen ve Rouse, 2016) için bu strateji kullanılır. Eşli okumalar esnasında eşler birbirinin hem akıcı okuma hem de okuduğunu anlama becerileri konusunda destekçisi olur, birbirlerinin okuma hatasını düzeltirler. Bu çalışmalar esnasında öğretmen sınıfta dolaşarak tüm grupları gözlemler, onların sözcükleri doğru okuduğu, doğru telaffuz ettiği ve anlama sorularını oluşturabildiğinden emin olur. Prozodik okumaları konusunda onları teşvik eder, geri bildirim verir ve önerilerde bulunur. Bir önceki gün çalışılan kelimelerin ağ haritası oluşturularak kelimelerin anlam ilişkileri ve anlam özellikleri üzerinde durulur. Kelime ağlarının kullanımı, kelime öğretimi açısından geleneksel olarak kullanılan tanım ezberleme ve kelimeyi bir cümle içinde kullanmaktan daha faydalı sonuçlar verir (Beck, McKeown, Sinatra ve Loxterman, 1991).

PERŞEMBE: Dördüncü gün artık gruplar ertesi gün yapacakları sunum için son provalarını yaparlar. Öğrencilerin sunum esnasındaki duruşları ve yerleri ayarlanır. Bu yöntemde kostüm ve aksesuar gerekmemektedir ancak öğrenciler istedikleri takdirde kendi evlerinden getirdikleri kravat, toka, fular gibi basit aksesuarlar kullanabilirler. Bu provalarda üzerinde durulan asıl konu prozodik okumadır. Öğretmen öğrencilerden metnin anlamını yansıtacak şekilde prozodik okumalarını ister ve gerekli uyarılarda bulunarak düzeltmeler yapar. Kelimelerin doğru telaffuz edildiğinden, vurgu ve tonlamanın doğru yerlerde yapıldığından ve noktalama işaretlerine dikkat edildiğinden emin olur. Sesli okuma çalışmaları tamamlandıktan sonra gruplar arası değişim yapılarak her gruptan bir öğrenci diğer gruptan bir öğrenciyle eşlenir. Öğrenci diğer gruptan olan arkadaşına yeni öğrendiği kelimeleri içerecek şekilde metni yeniden anlatır. Metnin ögelerini ve kronolojik sıralamasını doğru hatırlaması önemlidir. Bu özetlemedeki anahtar kavram yeni öğrenilen kelimelerin mutlaka kullanılmasıdır. Bu şekilde öğrenciler yeni öğrendikleri kelimeleri sözlü anlatımlarında kullanma fırsatı yakalarlar. Öğrencilerin öğrendikleri kelimeleri kendini ifade etme çalışmalarında kullanması kelimelerin deftere değil öğrencilerin zihnine ve yaşamına aktarıımasını sağlar (Yıldız, 2019).

CUMA: Beşinci gün öğrencilerin dört gün boyunca üzerinde çalıştıkları metni sunacakları büyük gündür. Öğrenciler hafta boyunca yaptıkları tekrarlı okumalar ve grup çalışmaları sonunda ulaştıkları okuma performansını dinleyicilere sunma fırsatı yakalarlar. Sınıfa öğretmenler, veliler, okul idaresi ya 
da diğer sınıflardan öğrenciler davet edilebilir. Gruplar sunumu yaparken diğer öğrenciler okuma tiyatrosu grup değerlendirme formlarını doldurarak arkadaşlarının okumalarını değerlendirirler. Sunumlar tamamlandıktan sonra değerlendirmeler yapılır ve en başarılı grup seçilir. Sunum günü başarıı bir okuyucu olmak, günlerce yapılan kapsamlı uygulamanın asıl amacıdır ve başarma duygusu öğrencileri motive eder (Rasinski, 2010). Sunum bittikten sonra öğrencilerin sergilenen performans ve okuma başarıları üzerine konuşması ve grupları değerlendirmesi onların değerlendirme ve öz düzenleme becerilerinin gelişimine katkı sağlar. Öğrenciler bir sonraki uygulamada neler yapmaları gerektiği konusunda kararlar alarak çalışmayı tamamlarlar.

\section{Okuma Tiyatrosunda Metin Seçimi}

Öğrencileri birçok yönden destekleyen bir yöntem olan okuma tiyatrosundan etkili sonuçlar elde edilebilmesi için dikkat edilmesi gereken bazı temel noktalar bulunmaktadır. Bunlardan ikisi metin seçimi ve rol dağılımıdır. Metin seçiminde öğrencinin ilgisini çekecek, çalışırken eğlenmesini sağlayacak nitelikli edebî eserler seçilmesine özen gösterilmesi gerekmektedir. Metin seçilirken edebiyatın her alanından yararlanılabilmekte; resimli çocuk kitapları, masallar, ders kitaplarındaki metinler, şiirler, marşlar vb. birçok materyal doğrudan ya da uyarlanarak kullanılabilmektedir. Tematik bir yaklaşım benimsenmek isteniyor ise belirlenen temaya ilişkin konularda öyküleyici, bilgilendirici ya da şiir türünde metinler seçilebilmektedir. Eğer uygun bir metin bulunamıyor ise de öğrenciler ya da öğretmen tarafından bir metin oluşturulabilmektedir. Dixon (2010) okuma tiyatrosu için metinler hazırlanırken içeriğin güncel olaylar, tarih, sanat, doğal olaylar ya da çevreyle ilişkilendirilebileceğini belirtmektedir. Flynn (2004) okuma tiyatrosu metinlerinin amaçlı bir şeklide ders içeriğiyle uyumlu bir şekilde yazılabileceğini, tüm dersler için uygun metinler hazırlanabileceğini ve ders içeriklerinin akılda kalması için bu yöntemin çok önemli bir fırsat sunduğunu savunmaktadır. Bu iddiasını da tekrarın öğrenmede ve bilgiyi kısa süreli bellekten uzun süreli belleğe göndermedeki etkisi üzerine inşa etmektedir. Ancak bir metin oluşturmak hem zaman hem de çaba gerektiren bir süreçtir. Bu nedenle öncelikle hazır metinler ve bunların uyarlanması üzerine çalışılmalı, bu çalışmalarda yeterince deneyim kazanıldıktan sonra metin yazma çalışmalarına geçilmelidir. Öğrenciler bu yaklaşıma aşina olup, birçok uygulama gerçekleştirdikten sonra onlardan kendi senaryo metinlerini oluşturmaları istenmelidir. Burada dikkat edilmesi gereken husus öğrencilere nitelikli eserlerle birçok kez karşılaşma fırsatı sunulması ve daha sonra onlardan böyle bir görev beklentisine girilmesidir. Ayrıca öğrencilerin senaryo metinlerini arşivlediği bir dosya tutmalarına özen gösterilmelidir. Bu şekilde her öğrenci yıl boyunca çalıştığı metin arşivine sahip olacak ve metinlerin kaybolma ve dağınık yerlerde durma olasılığı ortadan kaldırılmış olacaktır.

Metinlerin sınıftaki her öğrencinin bireysel bir role sahip olmasına yetecek kadar bölüm/rol/görev içermesine dikkat edilmesi gerekmektedir. Senaryoda daha az görev üstlenen öğrencilerin kendilerini daha zayıf okuyucular olarak görmelerini veya okumaya olan ilgi ve isteklerini kaybetmelerini önlemek için her öğrenciye, senaryonun mümkün olduğunca eşit bir bölümünü okuma fırsatı verilmelidir. Okuyucular arasında eşitliği sağlamak için okuyuculara birden fazla bölüm veya rol atanabilir. Rol dağııımında karakterlerin yanı sıra anlatıcı da önemli bir görev üstlenmektedir. Anlatıcı kitaptaki olay sıralanışını ve karakterlerin birbiriyle olan ilişkilerini sesine ve ifadelerine yansıtır. Geçişleri sağlar ve olayların arka planını anlatır. Gerekli açıklamaları yapar ve detayları verir. Ele alınan eserin senaryoya dönüştürülmeden önceki halinin ayrıntıları, detayları hatta resimlerdeki tamamlayıcılık anlatıcı sayesinde dinleyicilere aktarıır. Bu sebeple de anlatıcının işlenen eseri çok iyi tanımış ve anlamış olması gerekmektedir. Tüm bunlar göz önünde bulundurularak metin seçimi ve görev dağııımı sırasında hassas davranılmalı, öğrencileri okuma çalışmalarına motive edecek bir sınıf ortamı oluşturulmaya çalışıımalıdır.

\section{Sonuç ve Sınırlılıklar}

Okuma tiyatrosu okuma eğitiminde etkili olduğu kabul edilen ve birçok araştırmada (Aşıkcan, 2019; Babacan, 2020; Carrick, 2000; Çayır, 2014; Clark ve diğerleri, 2009; Flynn, 2004; Garrett ve O'Connor, 2010; Griffith ve Rasinski, 2004; Kanık Uysal, 2020; Kanık Uysal ve Duman, 2020; Keehn, 2003; Martinez, Roser ve Strecker, 1998; Millin ve Rinehart, 1999; Smith, 2011; Uribe, 2019; Young ve 
diğerleri, 2019; Young ve Rasinski, 2009) kullanılan bir yöntemdir. Okuma tiyatrosunun dayandığı kuramsal temeller bu yöntemin öğrencileri farklı yönlerden desteklediğini göstermektedir. Yöntemin tekrarlı okumalar ile otomatikliği teşvik etmesi okuduğunu anlamanın gelişimini desteklemekte (Garrett ve O'Connor, 2010; LaBerge ve Samuels, 1974; Logan, 1988; Millin ve Rinehart, 1999), tekrar tekrar okuma yapmak için öğrencilere gerçek bir neden sunması öğrencilerin okuma motivasyonunu artırmakta (Martinez ve diğerleri, 1998; Young ve diğerleri, 2019), akran ve öğretmen desteği ile iş birliğine dayalı öğrenmenin kapılarını açması öğrencilerin kendilerine olan güveninin artmasını (Corcoran ve Davis, 2005; Millin ve Rinehart, 1999) sağlamaktadır. Otomatiklik teorisine göre (LaBerge ve Samuels, 1974) tekrarlı okumalardan sonra öğrenciler kelime tanımada otomatikleştiği, kelimeleri daha hızlı ve doğru okuyabildiği için bilişsel kaynakları okuduğunu anlamak için serbest kalmaktadır. Bununla birlikte bu yöntemde yapılan tekrarlı okumalar yalnızca okuma hızını artırmak için değil metnin anlamını yansıtacak şekilde prozodik okumanın geliştirilmesi için yapılmaktadır. Amaç metindeki anlamın ve karakterlerin duygularının dinleyiciye yansıtılabilmesidir. Okuma tiyatrosunda öğrenciler sadece doğru ve uygun hızda okumanın ötesine geçerek anlamın okumaya yansıtıldığı prozodik okuma becerisini deneyimlemekte ve bu performansını dinleyiciler önünde sergileme şansı elde etmektedir. Bunu yaparken de iş birliği içinde akranlarıyla birlikte çalışma fırsatı yakalamaktadır. Sınıf içinde iş birliğine dayalı bir ortamın oluşturulması da öğrenme ortamının zenginleşmesini sağlamaktadır (Johnson ve Johnson, 1999; Slavin, 1987). Aynı senaryo metni üzerinde okuma becerileri birbirinden farklı olan öğrenciler çalışabildikleri için sınıfta heterejon gruplar oluşmaktadır (Flood, Lapp, Flood ve Nagel, 1992). Bunun yanı sıra aynı metin üzerinde yürütülen tartışmalar öğrencilerin farklı okur tepkilerini görebilmelerini (Rosenblatt, 1978) aynı olaya farklı bakış açılarıyla yaklaşabilmelerini sağlamaktadır.

Okuma tiyatrosu alanyazında ilk olarak okuma akıcılığını destekleyen bir yöntem olarak kullanılmış ve bu çalışmalar (Carrick, 2000; Clark ve diğerleri, 2009; Garrett ve O'Connor, 2010; Griffith ve Rasinski, 2004; Keehn, 2003; Martinez ve diğerleri, 1998; Millin ve Rinehart, 1999; Smith, 2011; Young ve Rasinski, 2009) okuma tiyatrosunun akıcı okuma becerileri üzerinde etkili olduğunu göstermiştir. Örneğin Martinez ve diğerleri (1998) bu yöntemin öğrencilerin akıcı okuma becerilerini geliştirdiğini, okuma tutumunu olumlu yönde etkilediğini, Vasinda ve McLeod (2011) teknoloji ile okuma tiyatrosunun bir araya getirilmesi sonucu öğrencilerin genel okuma başarısının arttığını, Clark vd. (2009) bu yöntemin öğrencilerin hem okuma motivasyonunu hem de kendilerine olan güvenlerini artırdığını tespit etmiştir. Öğrenciler ve öğretmenler üzerindeki bu olumlu etkileri görülerek zaman içerisinde yöntemin kapsamı genişletilmiştir. Young vd. (2017) okuma tiyatrosu artı anlama ve kelime çalışmaları adlı araştırmalarıyla okuma tiyatrosunun haftalık ders içeriğini tekrar düzenlemişler, okuma tiyatrosunda yeni bir yaklaşım olarak tanıttıkları bu çalışmalarında okuma tiyatrosunun haftalık formatına akıcı okuma yöntemlerinin yanı sıra okuduğunu anlama ve kelime öğretimi stratejilerini eklemişlerdir. Sonrasında yürütülen araştırmalarda da bu uygulamanın akıcı okuma, okuduğunu anlama ve kelime hazinesinin geliştirilmesinde etkili olduğu sonuçlarına ulaşılmıştır (Young ve diğerleri, 2019; Young, Lagrone ve McCauley, 2020). Okuma gibi karmaşık ve içinde birçok değişkeni barındıran bir becerinin sadece bir yönüne odaklanılması, okumada asıl amaç olan anlama ulaşmada yetersiz kalacağından dolayı özellikle ilkokul ve ortaokul yıllarında okuma tiyatrosunda akıcı okuma, okuduğunu anlama ve kelime öğretimi mutlaka yer verilmesi gereken temel stratejilerdir. Akıcı okuma (Baştuğ ve Keskin, 2012; Karadağ, Keskin ve Gökhan, 2019; Yamaç ve Sezgin, 2018), kelime bilgisi (Yıldırım, Yıldız ve Ateş, 2011) ve okuma stratejileri (Baydık, 2011; Belet ve Yaşar, 2007; Muijselaar ve diğerleri, 2017; Temizkan, 2008) ile okuduğunu anlama arasındaki ilişkiyi inceleyen araştırmalar bu değişkenlerin okuduğunu anlama üzerinde önemli yordayıcılar olduğunu göstermektedir. Stahl (1999) ve Rasinski (2010) akıcı okuma ve kelime hazinesinin geliştirilmesi için yapılabilecek en önemli çalışmalardan birinin öğrencileri mümkün olduğunca çok okumaya teşvik etmek olduğunu ifade etmekte, Graves (2016) de öğrencilerin zengin bir kelime dağarcı̆̆ına sahip olabilmesini, okuma miktarı ve çeşitliliğinin artırılmasına bağlamaktadır. Bu açıdan değerlendirildiğinde de okuma tiyatrosu öğrencilerin okuma miktarını ve çeşitli edebî eserlerle karşılaşma olanağını artıran bir yöntem olarak karşımıza çıkmaktadır. Ayrıca okuma stratejileri okuduğunu anlama üzerinde çok önemli bir yordayıcı olmasına rağmen yapılan araştırmalar (Ateş ve Yıldırım, 2014; Baydık, 2011; Pressley ve diğerleri, 1998) öğretmenlerin 
okuduğunu anlama stratejileri öğretiminde yetersiz olduğunu ortaya koymaktadır. Bu nedenle öğretmenlerin öğrencilerine model olacağı ve anlama stratejilerinin kazandırılmasına yönelik doğrudan öğretim etkinliklerine yer verebileceği sınıf içi uygulamalara intiyaç duyulmaktadır. Bu yönüyle de okuma tiyatrosu prozodik modelleme ve sesli düşünme stratejileriyle öğrencilere akıcı okuma ve okuduğunu anlama sürecini modellemektedir. Flynn (2004) model almanın hem akıcı okuma hem de okuma stratejilerini kullanma becerisinin gelişimini desteklediğini ve tekrarın kalıcı öğrenmeyi ya da akılda tutmayı artırdığı temelinden hareketle ders içeriklerinin öğrenilmesinde de okuma tiyatrosu yönteminin etkili olduğunu tespit etmiştir. Aynı şekilde Uribe (2019) de ikinci dil öğretiminde akademik içeriğin öğrenilmesi ve okuma becerilerinin geliştirilmesinde okuma tiyatrosunun etkili bir yöntem olduğunu tespit etmiş, aynı anda hem akademik içeriği öğrenme hem de ikinci bir dili öğrenme mücadelesi içinde olan öğrenciler için bu yöntemin etkili olduğu sonucuna ulaşmıştır. Bu yönüyle de okuma tiyatrosu ikinci dil öğretiminde kullanılan ve Yabancılara Türkçe Öğretimi alanında da yararlanılabilecek bir yöntem olarak karşımıza çıkmaktadır. Uribe (2019) ikinci dil öğrenen öğrencilerin bu yöntem sayesinde okuma kaygılarını yendiklerini, yavaş yavaş kendilerine güven kazandıklarını ve grup çalışmaları sayesinde uyum sürecini daha kolay atlattıklarını ifade etmektedir. Millin ve Rinehart (1999) ve Rinehart (2001) okuma güçlüğü yaşayan öğrenciler için de bu durumun geçerli olduğunu belirtmekte; Garrett ve O'Connor (2010) öğrenme güçlüğü yaşayan ilkokul düzeyindeki öğrencilerin akıcı okuma becerilerini ve sosyal gelişimini teşvik etmek için bu yöntemin kullanılabileceğini ifade etmektedir.

Okuma tiyatrosu tekrarlı okumalar, öğretmenle ve akranlarla birlikte yürütülen iş birliğine dayalı çalışmalar sayesinde öğrencilerin akıcı okuma ve anlama becerilerinin gelişimini destekleyen bir yöntem olmakla birlikte hiçbir yöntemin tek başına her konuda yeterli olamayacağının ve bazı sınırlılıklarının olduğunun göz önünde bulundurulması gerekmektedir. Bu yöntem, sınıf ortamında uygulanan ve grup çalışmalarının sağlıklı yürütülmesini gerektiren bir uygulama süreci içermektedir. Öğrencilerin grup çalışmalarına uyum sağlayabilmeleri, kendi görevlerini yerine getirme ve akranlarına gerekli desteği sunabilmeleri açısından öğretmen rehberliği ve takibi çok önemlidir. Gruplar kendi içlerinde çalışmalarını sürdürürlerken öğretmenin sınıfta sürekli dolaşması, grupların çalışmalarını nasıl yürüttüklerini gözlemlemesi gerekmektedir. Her grup hatta her öğrenciye geri bildirim verilmesi, üstlenilen görevin gereklerini yerine getirinceye kadar da bu geri bildirimlerin devam etmesi gerekmektedir. Bu nedenle bu uygulamalar kalabalık sınıf ortamlarında sorun oluşturabilecek, her gruba yeterli ve sağlıklı geri bildirim verebilme konusunda öğretmenin işini zorlaştırabilecektir. Aynı zamanda kalabalık sınıf ortamlarında grupların oluşturulması ve görev dağılımları konusunda sorunlar yaşanabilecektir. Her öğrenciye görev düşecek şekilde bir metin bulmak ya da yazmak kolay bir süreç değildir. Görev dağılımında yaşanacak muhtemel sorunların önüne geçebilmek adına birden çok metnin kullanılması tercih edilip her gruba ayrı metin dağıtılarak bu metinler üzerinde çalışılması ve her grubun sunumunu farklı bir metinle yapması sağlanabilir. Birden çok metnin kullanılması okuduğunu anlama çalışmalarına ayrılan zamanın daha uzun tutulmasına neden olacağı için de uygulama süresinin uzatılması gerekmektedir. Bu zaman planlamasını etkileyen bir diğer husus da metnin uzunluğu ve zorluk düzeyidir. Öğretmenin tüm bu değişkenleri göz önünde bulundurarak zaman planlamasını yapması, bazı metinler için iki ya da üç hafta süre ayırması gerekmektedir. Uzun ve okunabilirlik düzeyi zor olan metinlerin üst sınıflarda; kısa ve okunabilirlik düzeyi kolay ya da orta olan metinlerin ilkokulun ilk yıllarında kullanılması metin seçiminden kaynaklanacak sorunların asgari seviyede tutulmasına yardımcı olacaktır.

Çoklu strateji kullanımını gerektiren okuma tiyatrosu öğrencilerin öğrenme ortamlarını zenginleştirmekte aynı zamanda öğretmenlere strateji öğretimi konusunda büyük sorumluluklar yüklemektedir. Bu yöntemde geçen akıcı okuma, okuduğunu anlama ve kelime öğretimi stratejileri hakkında öğretmenin yeterli bilgiye sahip olması, kullanılacak stratejilere uygulamanın yapılacağı sınıf düzeyi, öğrenci grupları ve öğretim programında yer alan kazanımlar doğrultusunda karar vermesi gerekmektedir. Örneğin kelime öğretimi stratejilerinden kelime unsurlarından yararlanma, kelimeyi kök ve eklerine ayırma stratejisini (Tağa, 2018) kullanabilmek için uygulama yapılan sınıfın ez az 5. sınıf düzeyinde olması gerekmektedir. Özetleme stratejisi ise 1.sınıftan itibaren önce okuduklarını ana hatlarıyla anlatma sonra kronolojik sırayı gözeterek anlatma gibi zorluk düzeyi ve işlem basamakları 
artarak devam eden bir stratejidir. Bu nedenle öğrenciden beklenen görevler kendi sınıf düzeyinin kapsamı içinde değerlendirilmeli, onlardan bu doğrultuda görevler beklenmeli, uygulamanın yürütüleceği sınıf düzeyi ya da öğrenci grubuna göre kullanılacak okuma stratejilerine karar verilmelidir.

Bu çalışmada kuramsal temelleri ve uygulama aşamaları hakkında bilgi verilen okuma tiyatrosu yönteminin sınıf ortamında ne kadar etkili olduğu, yaşanabilecek sorunların neler olabileceği, bu sorunlara nasıl çözümler üretilebileceği ve uygulamaların nasıl daha keyifli ve etkili hale getirilebileceğinin tespit edilebilmesi için sınıf ortamında uygulanacak eylem araştırmaları ve deneysel çalışmalara intiyaç duyulmaktadır. Bu doğrultuda şu önerilerde bulunulabilir:

- Uygulamalar esnasında karşılaşılabilecek olası güçlüklerin tespit edilmesi ve bu sorunların nasıl giderilebileceğini açıklayan eylem araştırmaları yürütülebilir.

- Okuma güçlüğü yaşayan ya da ikinci dil öğrenen öğrenci gruplarında hangi okuma ve kelime öğretimi stratejilerinin kullanılabileceğini anlatan yapılandırılmış etkinlik önerileri hazırlanarak bu etkinliklerin etkililiğini tespit edecek deneysel araştırmalar yürütülebilir.

- Öğrencilerin okuma gelişimlerinin daha iyi desteklenebilmesi için bu yöntemin farklı hangi stratejilerle zenginleştirilmesi gerektiği araştırılabilir.

- Okuma tiyatrosunda kullanılabilecek edebî eserleri seçme kriterleri hazırlanıp bu doğrultuda bir eser listesi oluşturulabilir. Eser seçkisi elektronik ortamda tüm öğretmenlerin kullanımına sunulabilir.

- Edebî eserler uyarlanırken nelere dikkat edilmesi gerektiği ve yeni metin yazma aşamalarında nasıl bir yol takip edilmesi gerektiğiyle ilgili kılavuzlar hazırlanabilir.

\section{Yazarların Katkı Oranı}

Makale, yazarın kendisi tarafından tek başına hazırlanmıştır.

\section{Çıkar Çatışması}

Çıkar çatışması teşkil edebilecek durumlar ve ilişkiler bulunmamaktadır.

\section{Kaynaklar}

Aşıkcan, M. (2019). Üçüncü sınıf öğrencilerinin akıcı okuma becerilerinin geliştirilmesine yönelik bir eylem araştırması. Yayınlanmamış Doktora Tezi, Necmettin Erbakan Üniversitesi, Konya.

Ateş, S. ve Yıldııım, K. (2014). Sınıf öğretmenlerinin okuma becerisine yönelik uygulamaları: Strateji öğretimi ve anlama. Elementary Education Online, 13(1), 235-257.

Babacan, K. (2020). Okuyucu tiyatrosunun ilköğretim 4. sınıf öğrencilerinin akıcı okuma ve okuduğunu anlama becerilerine etkisi. Yüksek Lisans Tezi, Gazi Üniversitesi Eğitim Bilimleri Enstitüsü, Ankara.

Baştuğ, M. ve Akyol, H. (2012). Akıcı okuma becerilerinin okuduğunu anlamayı yordama düzeyi. Kuramsal Eğitimbilim Dergisi, 5(4), 394-411. http://www.keg.aku.edu.tr adresinden erişildi.

Baştuğ, M. ve Keskin, H. K. (2012). Akıcı okuma becerileri ile anlama düzeyleri (basit ve çıkarımsal) arasındaki ilişki. Ahi Evran Üniversitesi Kırşehir Eğitim Fakültesi Dergisi, 13(3), 227-244.

Baydık, B. (2011). Okuma güçlüğü olan öğrencilerin üstbilişsel okuma stratejilerini kullanımı ve öğretmenlerinin okuduğunu anlama öğretim uygulamalarının incelenmesi. Eğitim ve Bilim, 36(162), 301-319.

Beck, I. L., McKeown, M. G., Sinatra, G. M. ve Loxterman, J. A. (1991). Revising social studies text from a text-processing perspective: Evidence of improved comprehensibility. Reading Research Quarterly, 26(3), 251. doi:10.2307/747763

Belet, D. ve Yaşar, Ş. (2007). Öğrenme stratejilerinin okuduğunu anlama ve yazma becerileri ile Türkçe dersine ilişkin tutumları. Eğitimde Kuram ve Uygulama, 3(1), 69-86.

Beydoğan, H. Ö. (2012). Students' levels of using reading-comprehension strategies in relation to their proficiencies in reading fluently. Egitim ve Bilim, 37(166), 3-13.

Biemiller, A. ve Slonim, N. (2001). Estimating root word vocabulary growth in normative and advantaged populations: Evidence for a common sequence of vocabulary acquisition. Journal of Educational Psychology, 93(3), 498-520. 
Bouchamma, Y., Poulin, V. ve Ruel, C. (2014). Impact of reading strategy use on girls' and boys' achievement. Reading Psychology, 35(4), 312-331. doi:10.1080/02702711.2012.724043

Boulware-Gooden, R., Carreker, S., Thornhill, A. ve Joshi, R. M. (2007). Instruction of metacognitive strategies enhances reading comprehension and vocabulary achievement of third-grade students. The Reading Teacher, 61(1), 70-77. doi:10.1598/rt.61.1.7

Buikema, J. L. ve Graves, M. F. (1993). Teaching students to use context cues to infer word meanings. Journal of Reading, 36(6), 450-457. http://ezproxy.uno.edu/login?url=http://search.ebscohost.com/login.aspx?direct=true\&db=eric \&AN=ED155591\&site=ehost-live \&scope=site adresinden erişildi.

Buxton, J. A. (2017). An investigation of the relationships among high school students' reading comprehension strategy instruction, strategy use, attitudes, and achievement. Unpublished Doctoral Dissertation, George Mason University, Virginia.

Carrick, L. U. (2000). The effects of readers theatre on fluency and comprehension on fifth grade students in regular classrooms. Doctoral Dissertation, Lehigh University, Bethlehem, PA.

Carrick, L. U. (2006). Readers theatre across the curriculum. T. V Rasınskı, C. Blachowıcz ve K. Lems (Ed.), Fluency instruction research-based best practices içinde (ss. 209-228). New York: The Guildford.

Çayır, A. (2014). Akııılığı geliştirme programının ilkokul ikinci sınıf öğrencilerinin okuma ve anlama becerileri üzerindeki etkisi. Yayınlanmamış Doktora Tezi, Gazi Üniversitesi, Ankara.

Clark, R., Morrison, T. G. ve Wilcox, B. (2009). Readers' theater: A process of developing fourth-graders' reading fluency. Reading Psychology, 30(4), 359-385. doi:10.1080/02702710802411620

Corcoran, C. A. ve Davis, A. D. (2005). A study of the effects of readers' theater on second and third grade special education students' fluency growth. Reading Improvement, 42(2), 105-112.

Daane, M. C., Campbell, J. R., Grigg, W. S., Goodman, M. J. ve Oranje, A. (2005). The nation's report card: fourth-grade students reading aloud: NAEP 2002 special study of oral reading. The nation's report card (NCES 2006-469).

Davey, B. (1983). Think aloud: Modeling the cognitive processes of reading comprehension. Journal of Reading, 27(1), 44-47. http://www.jstor.org/stable/10.2307/40029295 adresinden erişildi.

Dixon, N. (2010). Readers Theatre a secondary approach. Winnipeg: Portage \& Main Press. http://ci.nii.ac.jp/naid/110009803847/ adresinden erişildi.

Dole, J. A., Duffy, G. G., Roehler, L. R. ve Pearson, P. D. (1991). Moving from the old to the new: Research on reading comprehension instruction. American Educational Research Association Stable, 61(2), 239-264.

Dowhower, S. L. (1991). Speaking of prosody: Fluency's unattended bedfellow. Theory Into Practice, 30(3), 165-175. doi:10.1080/00405849109543497

Duffy, G. G., Roehler, L. R. ve Herrmann, B. A. (1988). Modeling mental processes helps poor readers become strategic readers. Reading Teacher, 41(8), 762-67.

Durgunoğlu, A. Y. ve Öney, B. (1999). A cross-linguistic comparison of phonological awareness and word recognition. Reading and Writing, 11(4), 281-299. doi:10.1023/A:1008093232622

Fer, S. (2020). Ögrretim tasarımı (3. bs.). Anı Yayıncılık.

Flood, J., Lapp, D., Flood, S. ve Nagel, G. (1992). Am I allowed to group? Using flexible patterns for effective instruction. Reading Teacher, 45(8), 608-616.

Flynn, R. M. (2004). Curriculum-based readers theatre: Setting the stage for reading and retention. The Reading Teacher, 58(4), 360-365. doi:10.1598/rt.58.4.5

Garrett, T. D. ve O'Connor, D. (2010). Readers' theater: "Hold on, let's read it again." Teaching Exceptional Children, 43(1), 6-13. doi:10.1177/004005991004300101

Göçer, A. (2009). Türkçe eğitiminde öğrencilerin söz varlığını geliştirme etkinlikleri ve sözlük kullanımı. Turkish Studies, 4(4), 1025-1055.

Graves, M. F. (2016). The vocabulary book: Learning and instruction. New York: Teachers College.

Griffith, L. W. ve Rasinski, T. V. (2004). A focus on fluency: How one teacher incorporated fluency with her reading curriculum. The Reading Teacher, 58(2), 126-137. doi:10.1598/rt.58.2.1

Güldenoğlu, B., Kargın, T. ve Ergül, C. (2016). Effects of phonological awareness skills on reading and 
reading comprehension: A longitudinal study [Sesbilgisel farkındalık becerilerinin okuma ve okuduğunu anlama üzerindeki etkisi: Boylamsal bir çalışma]. Elementary Education Online, 15(1), 251-272. doi:10.17051/io.2016.25973

Güldenoğlu, B., Kargın, T. ve Miller, P. (2015). Okuma güçlüğü olan ve olmayan öğrencilerin cümle anlama becerilerinin incelenmesi. Türk Psikoloji Dergisi, 30(76), 82-100.

Hudson, R. F., Lane, H. B. ve Pullen, P. C. (2005). Reading fluency assessment and instruction: What, why, and how? The Reading Teacher, 58(8), 702-714. doi:10.1598/rt.58.8.1

Johnson, D. W. ve Johnson, R. T. (1985). Student-student interaction: Ignored but powerful. Journal of Teacher Education, 36(4), 22-26. doi:10.1177/002248718503600406

Johnson, D. W. ve Johnson, R. T. (1999). Making cooperative learning work. Theory Into Practice, 38(2), 67-73. doi:10.1080/00405849909543834

Joseph, L. M., Alber-Morgan, S., Cullen, J. ve Rouse, C. (2016). The effects of self-questioning on reading comprehension: A literature review. Reading and Writing Quarterly, 32(2), 152-173. doi:10.1080/10573569.2014.891449

Kanık Uysal, P. (2020). Akıcı okuma becerilerinin geliştirilmesinde okuma tiyatrosunun kullanılması : Bir eylem araştırması. Kırşehir Eğitim Fakültesi Dergisi, 21(2), 1202-1246.

Kanık Uysal, P. ve Duman, A. (2020). Akıcı okuma odaklı okuma öğretiminin okuma becerilerine etkisi. Pegem Eğitim ve Öğretim Dergisi, 10(4), 1111-1146. doi:10.14527/pegegog.2020.034

Karadağ, Ö., Keskin, H. K. ve Gökhan, A. (2019). Hızlı otomatik isimlendirme ve okuduğunu anlama ilişkisinde okuma becerisinin aracılık etkisi. Eğitim ve Bilim, 44(197), 353-366.

Karadağ, Ö. ve Kurudayıoğlu, M. (2010). 2005 Türkçe programına göre hazırlanmış ilköğretim birinci kademe Türkçe ders kitaplarının kelime hazinesi. Türklük Bilimi Araştırmaları, (27), 423-436.

Karatay, H. (2007). Kelime Öğretimi. Gazi Ĕgitim Fakültesi Dergisi, 27(1), 141-153.

Keehn, S. (2003). The effect of instruction and practice through readers theatre on young readers' oral reading fluency. Reading Research and Instruction, 42(4), 40-61. doi:10.1080/19388070309558395

Kinniburgh, L. ve Shaw, E. (2007). Building reading fluency in elementary science through readers' theatre. Science Activities: Classroom Projects and Curriculum Ideas, 44(1), 16-22. doi:10.3200/sats.44.1.16-22

Kuruyer, H. G. ve Özsoy, G. (2016). İyi ve zayıf okuyucuların üstbilişsel okuma becerilerinin incelenmesi: Bir Durum Çalışması. Kastamonu Eğitim Dergisi, 24(2), 771-788.

LaBerge, D. ve Samuels, S. J. (1974). Toward a theory of automatic information processing in reading. Cognitive Psychology, 6(2), 293-323. doi:10.1016/0010-0285(74)90015-2

Lee, J. ve Yoon, S. Y. (2017). The Effects of Repeated Reading on Reading Fluency for Students With Reading Disabilities: A Meta-Analysis. Journal of Learning Disabilities, 50(2), 213-224. doi:10.1177/0022219415605194

Logan, G. D. (1988). Toward an instance theory of automatization. Psychological Review, 95(4), 492527.

Martinez, M., Roser, N. L. ve Strecker, S. (1998). "I never thought I could be a star": A readers theatre ticket to fluency. Reading Teacher, 52(4), 326-334.

McNamara, D. S. (2007). Reading comprehension strategies: Theories, interventions, and technologies. Psychology Press. Mahwah, NJ: Erlbaum. doi:10.4324/9780203810033

Miller, J. ve Schwanenflugel, P. J. (2008). A longitudinal study of the development of reading prosody as a dimension of oral reading fluency in early elementary school children. Reading Research Quarterly, 43(4), 336-354. doi:10.1598/rrq.43.4.2

Millî Eğitim Bakanlığı (2005). Türkçe öğretim programı (1-5. Sınıflar). Ankara: Millî Eğitim Bakanlığı Yayınları, Ankara.

Millin, S. K. ve Rinehart, S. D. (1999). Some of the benefits of readers theater participation for secondgrade title I students. Reading Research and Instruction, 39(1), 71-88. doi:10.1080/19388079909558312

Moats, L. C. (1999). Teaching reading is rocket science: What expert teachers of reading should know and be able to do. (No. 372) Washington, DC: American Federation of Teachers. 
Muijselaar, M. M. L., Swart, N. M., Steenbeek-Planting, E. G., Droop, M., Verhoeven, L. ve de Jong, P. F. (2017). Developmental relations between reading comprehension and reading strategies. Scientific Studies of Reading, 21(3), 194-209. doi:10.1080/10888438.2017.1278763

National Reading Panel. (2000). Teaching children to read: An evidence-based assessment of the scientific research literature on reading and its implications for reading instruction. National Institute of Child Health and Human Development, National Institutes of Health. doi:10.1002/ppul.1950070418

Öney, B. ve Durgunoğlu, A. Y. (1997). Beginning to read in Turkish: A phonologically transparent orthography. Applied Psycholinguistics, 18(1), 1-15. doi:10.1017/s014271640000984x

Prado, L. ve Plourde, L. A. (2011). Increasing reading comprehension through the explicit teaching of reading strategies: Is there a difference among the genders? Reading improvement, 48(1), 3244.

Pressley, M. (2002). Comprehension instruction: What makes sense now, what might make sense soon. Reading Online, 5(2), 1-14.

Pressley, M. ve Gaskins, I. W. (2006). Metacognitively competent reading comprehension is constructively responsive reading: How can such reading be developed in students? Metacognition and Learning, 1(1), 99-113. doi:10.1007/s11409-006-7263-7

Pressley, M., Johnson, C. J., Symons, S., Mcgoldrick, J. A. ve Kurita, J. A. (1989). Improve children's memory and comprehension of text. The Elementary School Journal, 90(1), 3-32.

Pressley, M., Wharton-Mcdonald, R., Mistretta-Hampston, J. ve Echevarria, M. (1998). Literacy instruction in 10 fourth-grade classrooms in upstate New York. Scientific Studies of Reading, 2(2), 159-194. doi:10.1207/s1532799xssr0202_4

Rasinski, T. V. (2010). The fluent reader (2. bs.). New York: Scholastic.

Rasinski, T. V. ve Young, C. (2017). Effective instruction for primary grade students who struggle with reading fluency. International Perspectives on Inclusive Education, 11, 143-157. doi:10.1108/S1479-363620170000011010

Reutzel, D. R., Jones, C. D., Fawson, P. C. ve Smith, J. A. (2008). Scaffolded silent reading: A complement to guided repeated oral reading that works! The Reading Teacher, 62(3), $194-207$. doi:10.1598/rt.62.3.2

Rinehart, S. D. (2001). Establishing guidelines for using readers theater with less-skilled readers. Reading Horizons : A Journal of Literacy and Language Arts, 42(2), 65-75.

Rosenblatt, L. M. (1978). The reader, the text, the poem: The transactional theory of the literary work. Carbondale: Southern Illinois University Press.

Samuels, J. (1979). The method of repeated readings. The Reading Teacher, 32(4), 403-408. doi:10.1177/002221948301600205

Schreiber, P. A. (1991). Understanding prosody's role in reading acquisition. Theory Into Practice, 30(3), 158-164. doi:10.1080/00405849109543496

Silverman, R. D. ve Hartranft, A. M. (2015). Developing vocabulary and oral language in young children. New York: Guilford.

Slavin, R. E. (1987). Ability grouping and student achievement in elementary schools: A best-evidence synthesis. Review of Educational Research, 57(3), 293-336. doi:10.3102/00346543057003293

Smith, D. M. (2011). Readers theatre: Its effecttiveness in improving reading fluency, student motivation, and attitudes toward reading among second-grade students. Doctoral Dissertation, The Pennsylvania State University, Pennsylvania.

Stahl, S. A. (1999). Vocabulary development. Cambridge MA: Brookline.

Stahl, S. A. ve Heubach, K. M. (2005). Fluency-oriented reading instruction. Journal of Literacy Research, 37(1), 25-60. doi:10.1207/s15548430jlr3701_2

Stanovich, K. E. (1980). Toward an interactive-compensatory model of individual differences in the development of reading. Reading Research Quarterly, 16(1), 32-71. https://www.jstor.org/stable/747348 adresinden erişildi.

Tağa, T. (2018). Yazma etkinlikleriyle bütünleştirilmiş kelime öğretiminin kelime öğrenme, hatırlama ve farkındalığına etkisi. Doktora Tezi, Gazi Üniversitesi Eğitim Bilimleri Enstitüsü, Ankara. 
Temizkan, M. (2008). Bilişsel okuma stratejilerinin Türkçe derslerinde bilgiye dayalı metinleri okuduğunu anlama üzerindeki etkisi. Gazi Eğitim Fakültesi Dergisi, 28(2), 129-148.

Therrien, W. J. (2004). Fluency and comprehension gains as a result of repeated reading a metaanalysis. Remedial and special education, 25(4), 252-261.

Turan, F. ve Akoğlu, G. (2011). Okul öncesi dönemde sesbilgisel farkındalık eğitimi. Eğitim ve Bilim, 36(161), 64-75.

Uribe, S. N. (2019). Curriculum-based readers theatre as an approach to literacy and content area instruction for English language learners. Reading and Writing Quarterly, 35(3), 243-260. doi:10.1080/10573569.2018.1526726

Vasinda, S. ve McLeod, J. (2011). Extending readers theatre: A powerful and purposeful match with podcasting. The Reading Teacher, 64(7), 486-497. doi:10.1598/rt.64.7.2

Vaughn, S., Chard, D. J., Bryant, D. P., Coleman, M., Tyler, B. ve Linan-thompson, S. (2000). Fluency and comprehension interventions for third-grade students. Remedial and Special Education, 21(6), 325-335. doi:https://doi.org/10.1177/074193250002100602

Vygotsky, L. S. (1978). Mind in society. The development of higher mental processes. Cambridge: Harvard University.

Wade, S. E. ve Trathen, W. (1989). Effect of self-selected study methods on learning. Journal of Educational Psychology, 81(1), 40-47. doi:10.1037/0022-0663.81.1.40

Worthy, J. ve Prater, K. (2002). The intermediate grades:" I thought about it all night": Readers theatre for reading fluency and motivation. The Reading Teacher, 56(3), 294-297.

Yamaç, A. ve Sezgin, Z. Ç. (2018). Relationships among fourth graders' reading anxiety, reading fluency, reading motivation, and reading comprehension. Egitim ve Bilim, 43(194), 225-243. doi:10.15390/EB.2018.7555

Yıldıım, K. (2010). İş birlikli öğrenme yönteminin okumaya ilişkin bazı değişkenler üzerindeki etkisi ve yönteme ilişkin öğrenci-veli görüşleri. Yayımlanmamış Doktora Tezi, Gazi Üniversitesi, Eğitim Bilimleri Enstitüsü, Ankara.

Yıldırım, K. ve Rasinski, T. (2014). Reading fluency beyond English: Investigations into reading fluency in Turkish elementary students. International Electronic Journal of Elementary Education, 7(1), 72-81.

Yıldırım, K., Yıldız, M. ve Ateş, S. (2011). Kelime bilgisi okuduğunu anlamanın anlamlı bir yordayıcısı mıdır ve yordama gücü metin türlerine göre farklılaşmakta mıdır? Kuram ve Uygulamada Eğitim Bilimleri, 11(3), 1531-1547.

Yıldız, M. (2019). Kelime hazinesi ve anlama becerilerinin geliştirilmesi. H. Akyol ve A. Şahin (Ed.), Türkçe öğretimi içinde (ss. 129-179). Ankara: Pegem Akademi.

Yıldız, M., Yıldırım, K., Ates, S., Rasinski, T., Fitzgerald, S. ve Zimmerman, B. (2014). The relationship between reading fluency and reading comprehension in fifth-grade Turkish students. International Journal of School and Educational Psychology, 2(1), 35-44. doi:10.1080/21683603.2013.854187

Yılmaz, M. (2006). Illköğretim 3. sınıf öğrencilerinin sesli okuma hatalarını düzeltmede ve okuduğunu anlama becerilerini geliştirmede tekrarlı okuma yönteminin etkisi. Yayımlanmamış Doktora tezi, Gazi Üniversitesi, Eğitim Bilimleri Enstitüsü, Ankara.

Young, C., Durham, P., Miller, M., Rasinski, T. V. ve Lane, F. (2019). Improving reading comprehension with readers theater. Journal of Educational Research, 112(5), 615-626. doi:10.1080/00220671.2019.1649240

Young, C., Lagrone, S., \& McCauley, J. (2020). Read like me: An intervention for struggling readers. Education Sciences, 10(3). https://doi.org/10.3390/educsci10030057

Young, C., Mohr, K. A. J. ve Landreth, S. (2020). Improving boys' reading comprehension with readers theatre. Journal of Research in Reading, 43(3), 347-363. doi:10.1111/1467-9817.12307

Young, C. ve Rasinski, T. (2009). Implementing readers theatre as an approach to classroom fluency instruction. The Reading Teacher, 63(1), 4-13. doi:10.1598/rt.63.1.1

Young, C., Stokes, F. ve Rasinski, T. (2017). Readers theatre plus comprehension and word study. Reading Teacher, 71(3), 351-355. doi:10.1002/trtr.1629 
Zutell, J. ve Rasinski, T. V. (1991). Training teachers to attend to their students' oral reading fluency. Theory Into Practice, 30(3), 211-217. doi:10.1080/00405849109543502

\section{Extended Abstract \\ Introduction}

To develop reading comprehension, reading fluency, vocabulary knowledge and use of strategies should be dealt with together and these skills should support each other (Baydık, 2011; Pressley, 2001). Based on this, there is a need for reading education approaches involving teaching of these basic variables for successful reading skills. When the relevant literature is investigated, the method of readers theater, which may be used for reading education and involves work on reading fluency, comprehension strategies, and vocabulary teaching appear to come to the fore.

\section{Readers theater}

Readers theater is a teaching method including reading fluency, vocabulary teaching, and reading comprehension strategies which contributes to the development of students' fluency along with comprehension skills. Studies in the literature have defined readers theater as an effective teaching strategy to increase reading fluency (Young et al., 2020), an important teaching method for reading practice (Hudson et al., 2005), an effective teaching method including many features for successful fluency education (Rasinski and Young, 2017) and an educational activity encouraging students to rehearse and present scenario texts for an audience (Worthy and Prater, 2002).

Readers theater offers an enjoyable and real reason for repeated reading, targeting increased time spent reading by students. To be a proficient reader, sufficient time must be allocated to reading work; for this to occur students need to be presented with a motivating reason. Fun when reading and feeling support from teacher and peers motivates students for reading work and ensures more easy transition for them. Readers theater differs from the theater in not requiring stage, costumes, and memorization and can be easily performed in the class environment. Teachers do not encounter financial problems and space difficulties representing an obstacle to presentation work with students; in other words, they don't have to deal with external factors that are limiting or develop outside themselves. This method can be easily implemented in the class environment with a chosen text and does not require a preparation process lasting months and memorization studies. The important thing is to select an appropriate text for the level and interest area of students involving conversations and to transform the text into a scenario. After selecting the correct text and transforming it into a scenario, then text comprehension and reading fluency studies are next. At the end of reading fluency and reading comprehension work accompanied by the text, students present to their friends, teachers, school management, parents, or guests. Model reading, repeated reading, partner reading, comprehension strategies, and vocabulary teaching work before the presentation increase the reading success of students. Assessment work after the presentation provides the students with awareness of their own and their friends' reading ability targeting the development of self-and peer-assessment skills.

\section{Discussion and Recommendations}

The conceptual basis of readers theater shows the method supports students from different aspects. The method encourages repeated reading and automatic information processing supporting the development of comprehension (Garrett \& O'Connor, 2010; LaBerge \& Samuels, 1974; Logan, 1988; Millin \& Rinehart, 1999), it provides a real reason for students to read over and over increasing student's reading motivation (Martinez et al., 1998; Young et al., 2019), and opens the doors for cooperation-based learning with peer and teacher support increasing student's self-confidence (Corcoran \& Davis, 2005; Millin \& Rinehart, 1999). According to the theory of automatic information processing (LaBerge \& Samuels, 1974), after repeated reading students automatically recognize words, and can read words more rapidly and correctly freeing cognitive resources to understand what is read. Additionally, repeated reading with this method does not only increase reading speed but is performed to develop prosodic reading to reflect the meaning of the text. The aim is to reflect the meaning of the 
text and the emotions of the characters for the listener. Most of the time students confuse reading fluency with rapid reading. The sentence "I want you to read fluently" causes a misperception of I want you to read quickly among students. In fact, this situation is still valid even for some teachers; these teachers want students to read in a serial way, quickly and without pauses, but ignore whether the reading reflects the meaning or not. It is necessary to use this method to remove this misperception. Rapid reading remains inadequate to reflect meaning and at this point prosodic reading skills become a very important variable which may be shown to students in practice with this method. Students must pass beyond just reading accurately and at appropriate speed and reflect the meaning in reading, experiencing prosodic reading skills and have the chance to display this performance to listeners. While doing this, they gain the opportunity to work in cooperation with peers. Creation of a cooperationbased environment within the class ensures enrichment of the learning environment (Johnson \& Johnson, 1985; Slavin, 1987). As students with different reading skills work on the same scenario, heterogeneous groups form in the class (Flood, Lapp, Flood \& Nagel, 1992); cooperative work in these groups ensures students learn from peers and support each other (Vygotsky, 1978). Additionally, students may see different reading reactions in discussions about the same text (Rosenblatt, 1978) and become aware of different perspectives on the same event.

There is a need for active research to be applied in class environments about readers theater, with information about conceptual basis and implementation stages given in this study, to identify how effective it is, what problems may be experienced, what solutions may be produced for these problems and how to make the implementation more enjoyable and effective. 